\title{
Determinants of Poverty Reduction: A Relative Panel Data Analysis Between Positive and Negative Poverty Reduction Economies
}

\author{
Tariro Madzimure ${ }^{\mathbf{1}}$ and Edson Mbedzi $^{2}$ \\ ${ }^{1,2}$ National University of Science and Technology, Department of Finance, P.O. Box AC 939, Ascot, Corner Cecil \\ Avenue and Gwanda Road, Bulawayo, Zimbabwe
}

\begin{abstract}
The study compares the effects of macroeconomic factors on poverty between positive and negative poverty reduction economies using panel data from 1991 to 2018. Performing a fixed effects model, the results indicate that from the whole sample, only interest and unemployment rate affect poverty while inflation does not. However, individualistic country characteristics suggest that poverty is deep-rooted more on the ability of the population to access funds from either employment income or financial markets than on prices of goods and services effects. This implies different policies be implemented to reduce poverty based on the level of income distribution and country structural income classification status as a low, middle or high income country. Conclusively, intervening policies implemented to reduce poverty yield the same results whether a country is a positive or negative poverty reduction economy, meaning this classification does not matter for policy targeting purposes, rather determinant macroeconomic factors do.
\end{abstract}

Key words: poverty, inflation, unemployment, interest rate, panel data JEL: E24, E25, E64

\section{Introduction}

Poverty has always been the greatest enemy to mankind and is at the center of human livelihoods. Roughly one in five Africans is deprived of food, clean water, and medicines (Dulani, Mattes, \& Logan, 2013; World Bank, 2018a). Approximately half of the African population has experienced occasional shortages and many suffered from inadequate access to basic needs (Dulani et al., 2013; World Bank, 2018a). Poverty has even affected other various social aspects in human beings such as moral, physical and psychological wellbeing (Anwar, Zaman, Amir, \& Amin, 2018; Collins \& Wanjau, 2011). There are three scales of measuring poverty: absolute, relative or core poverty (Collins \& Wanjau, 2011; Sembene, 2015). However literature indicate that it is impossible to eliminate relative and core poverty but absolute poverty can be reduced by economic growth (Ravallion, 2012) through growth-mediated security strategies in which benefits 
of economic growth trickles down to the poor. Economies that have embraced such strategies reported varied success stories except for developing economics where poverty remained imbedded due to the region's lower GDP per capita stimulation (Sembene, 2015; World Bank, 2018a). Several empirical studies confirmed macroeconomic variables are the main determinants of economic growth (Castleman, Foster, \& Smith, 2015; Kashi \& Tash, 2014). Therefore, it becomes indispensable to ignore the drivers of economic growth and their relation to poverty (Epstein, Heintz, Ndikumana, \& Chang, 2010; Handley, Higgins, Bird, \& Cammack, 2009; World Bank, 2018a). Sadly, progress in poverty reduction has been uneven. Between 1990 and 2015, on average poverty levels decreased in most regions but it increased in some parts of Sub-Saharan Africa (World Bank, 2018b). Empirical studies have shown that high levels of inequality stifles the impact of GDP growth on poverty (Loayza \& Raddatz, 2010; Ravallion, 2010; Sembene, 2015; World Bank, 2018b). For countries to achieve "a world free of poverty" there is need to steer growth via the main determinants of economic growth such as inflation, interest rates, and unemployment levels that are directly linked to poverty levels (Kashi \& Tash, 2014; World Bank, 2018b). Rarely studies have been carried out to compare country specific macroeconomic fundamentals on poverty for successful and non-successful countries. Hence this paper therefore evaluates the effects of macroeconomic factors on poverty by comparing the outcomes in selected positive and negative poverty reduction economies. Capturing differences in poverty reduction patterns is critical in influencing policy that directly addresses the unique characteristics of countries.

\section{Literature}

Poverty is lack of basic needs such as food, shelter, medical care, education, employment, sanitation, power, representation and freedom of persons (Ravallion, 2012). According to Ravallion (2012) scholars have classified poverty into three categories 1) absolute poverty: living below a certain minimum standard or level of income or consumption acceptable by a particular society or culture, 2) relative poverty: a state of how poor one is relative to others and 3) core poverty: lack of minimum income and other basic resources. Literature notes that it is impossible to eliminate relative and core poverty whereas absolute poverty can through economic growth (Loayza \& Raddatz, 2010; Ravallion, 2012), hence the emphasis must be on absolute poverty. Keynesians theory hypothesises that economic growth alleviates poverty and thus government intervention is needed to address involuntary unemployment, mainly through fiscal and monetary policy (Davis \& Sanchez-martinez, 2014). Governments need to supplement, regulate, and exhort poverty for those who are involuntarily unemployed (Townsend, 1979). Aggregate investment was stated as the key element among the set of macroeconomic variables because of its positive impact on employment, effectively generating the necessary growth required to alleviate poverty (Davis \& Sanchez-martinez, 2015). Therefore if developing countries need to make progress on poverty reduction they had to work on improving GDP by combating negative effects of macroeconomic variables such as interest, inflation and unemployment rates on GDP (Romer \& Romer, 1998). 
While unemployment is a problem in its own right, it has been argued that the effects of unemployment lies most particularly in its correlation with poverty (Keynes, 1936). Keynes viewed unemployment as involuntary and a major cause of poverty (Davis \& Sanchez-martinez, 2014). The effects of unemployment as a primary source of poverty is rooted on the logic that if individuals do not receive labour income, they are destined to be poor (Anwar et al., 2018; Davis \& Sanchez-martinez, 2014, 2015), concurring with the World Poverty Commission that joblessness is the major cause of poverty (World Bank, 2018b). Growth in employment reduces poverty by pushing up the Lorenz income distribution curve towards the income distribution line of equality since most of the poor are clustered on the left of the curve (Khan, 2007) and hence the poor can escape poverty when they experience an increase in (i) wage employment; (ii) the real wage; (iii) self-employment, and (iv) productivity when in self-employment.

The employment and poverty relationship is also linked to personal capacity development (Budiantara, Diana, \& Darmesto, 2011). Intuitively, the improvements in the absorption capacity of the labour market reduces poverty perseverance by facilitating individuals to better career opportunities that allow higher future earnings, improve access to borrowing and investment in human and social capital (Nwagwu, 2014). However, empirical evidence on unemployment and poverty relationship often contradicts theory. For instance, Krantz (2001) found out that in the US poverty had a weak correlation with unemployment although the connection between poverty and unemployment is highly influenced by the method of poverty measurement. Equally, Sabir and Tahir (2012) concurred with the view, stating that unemployment rate was not a fitting poverty measure, because in general, unemployed people have a better living standard than those employed. A trade-off between poverty and unemployment emanating from specific policies such as increasing employment subsidies have beneficial impact on unskilled employment whereas if financed by a rise in taxes on domestic goods result in increased poverty, because of the negative effects that high taxes may have on the consumption and the wage cost of living (Agenor, 2016; Budiantara et al., 2011). Similarly, a reduction in unemployment in Germany actually led to poverty increase (Kyzyma, 2018). It was also noted that over half of the 14 million population living in poverty in the UK were coming from employed families (Davis \& Sanchez-martinez, 2014). Based on these findings, it becomes apparent to understand how does unemployment as one of the macroeconomic factors of economic growth affects poverty particularly between economies with different poverty trends.

Given the majority of households rely on the product market for the purchases of key commodities, inflation clearly becomes a factor to the poor and non-poor alike (Nwagwu, 2014). When average earnings on which low earners depend on stagnate or grow at a slower rate than price increases, inflation reduce workers' real earnings causing poverty (Davis \& Sanchezmartinez, 2014). Using a cross-section of 38 countries, Agenor (2016) posited that inflation increase the poverty rate while Easterly and Fischer (2001), Siyan, Adegoriola, and Adolphus (2017), Banerjee et al. (2008), Datt and Ravallion (2002) noted that the effects of inflation on poverty are more pronounced on the poor than the rich. In a panel data study of 12 years and 8 West African countries, Handley et al. (2009) found a very strong positive connection between 
consumption poverty rate and inflation. The banking school argues that money is generated by the intermediary sector and hence dispensing money for real bills during crises time does not necessarily lead to inflation but can promote investment and stimulate poverty reduction thus monetary policy directed at reducing inflation, have a reducing impact on poverty (Ekobena \& Yannick, 2012). Poverty may be positively related with inflation or the contrary also can be the case (UNECA, 2016). A separate analyses of the effect of inflation on poverty in low income countries, lower middle income countries, and upper middle income countries was carried out to see whether the effect of inflation is similar or different in countries with different levels of income showed that for low income countries, the relationship between inflation and poverty is negative but positive for middle and upper income countries (Dulani et al., 2013). This then means that the level of income inequality of a country becomes an important factor to explain the effects of inflation on poverty (Anwar et al., 2018).

Interest rate measures cost of capital (Ioris, 2016; A. Khan, 2007; B. U. I. Khan, Langoo, Olanrewaju, Baba, \& Assad, 2017). According to Keynes (1936), interest rate represents the cost of borrowing capital and due to the fact that borrowing is a significant source of finance for many households, prevailing interest rates affect the indexing of interest rate on borrowing arrangements of the households ultimately affecting growth and poverty levels. Interest rate trends impact on saving and consumption behavior of households, decisions of firms on capital accumulation and the portfolio allocation of foreign and domestic investment which all influence the expectations and future plans of economic agents, their perception about welfare and redistribution of income and the prospects of the economy (Keynes, 1936).

Empirically, interest rate and poverty are positively correlated in the United States (Ekobena \& Yannick, 2012) and in South Korea (Fan \& Chan-kang, 2005), indicating that the growing interest rate increases poverty. Two reasons seems to be behind this reasoning (Bourguignon, 2004). First, most poor people are net debtors so for them higher interest rate are a burden, causing them to cut back their spending (Ekobena \& Yannick, 2012). Second, other than being net debtors, people in poverty endure high substitution effects of interest rate. When interest rate rises, opportunity cost of present consumption rises too, subsequently reducing current spending. Therefore poor people are forced to cut back consumption, causing greater poverty severity (Ekobena \& Yannick, 2012). Accordingly, high interest rates have the negative effect of increasing the cost of borrowing and consequently limiting the level of aggregate investment and consumption and the overall economic growth in the country (Collins \& Wanjau, 2011). While both theory and empirical positions of these microeconomic factors such as unemployment, inflation and interest rates are a well-documented subject, little is known about how their effects actually vary or conform between positive and negative absolute-poverty reducing economies, which is the central objective of the analysis of this study. 


\section{Data and methods}

After a careful review of related literature, the study adopted the following conceptual framework (Figure 1). The theoretical concepts were adopted from Kashi and Tash (2014) but adjusted to suit the merit of the study. It is theorized that the appropriate intervention by governments on interest, unemployment and inflation rates through fiscal and monetary policies influences the purchasing power of the population, determining poverty levels of the country.

\section{FIGURE 1: PURCHASING POWER TO POVERTY REDUCTION CONCEPTUAL FRAMEWORK}

\section{Government intervention on macroeconomic factors}

Unemployment

Inflation rates

Interest rates

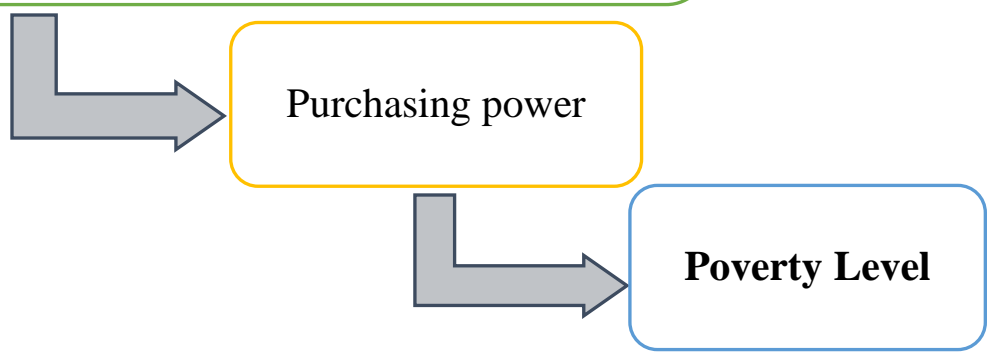

Source: Modified from Kashi and Tash (2014)

Based on the above analogy, the study thus hypothesises that a link between poverty and economic growth macroeconomic factors is premised on the country's poverty determinants and hence the variables map is guided as follows (Figure 2).

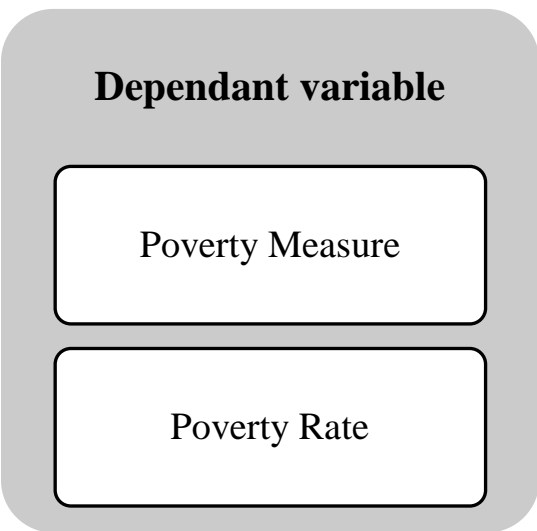

FIGURE 2: VARIABLES MAP

\section{Moderating variables}

Country charactersitics

1. Positive poverty reducing economy

2. Negative poverty reducing economy
Independnant varaibles

Macroeconomic factors

1. Inflation rate

2. Unemployment rate

3. Borrowing intersret rate

Source: deduced by authors 


\subsection{Sample and data}

A total sample of ten countries was used comprising Brazil, China, India, Ghana, Namibia, Nigeria, South Africa, Uganda, Vietnam and Zambia for the period 1991 to 2018. The selection of countries was influenced primarily by the availability of balanced data. The data shows that at a glance, poverty rate is decreasing for all the countries during the period under study (Figure 3).

FIGURE 3: POVERTY TREND BY COUNTRY

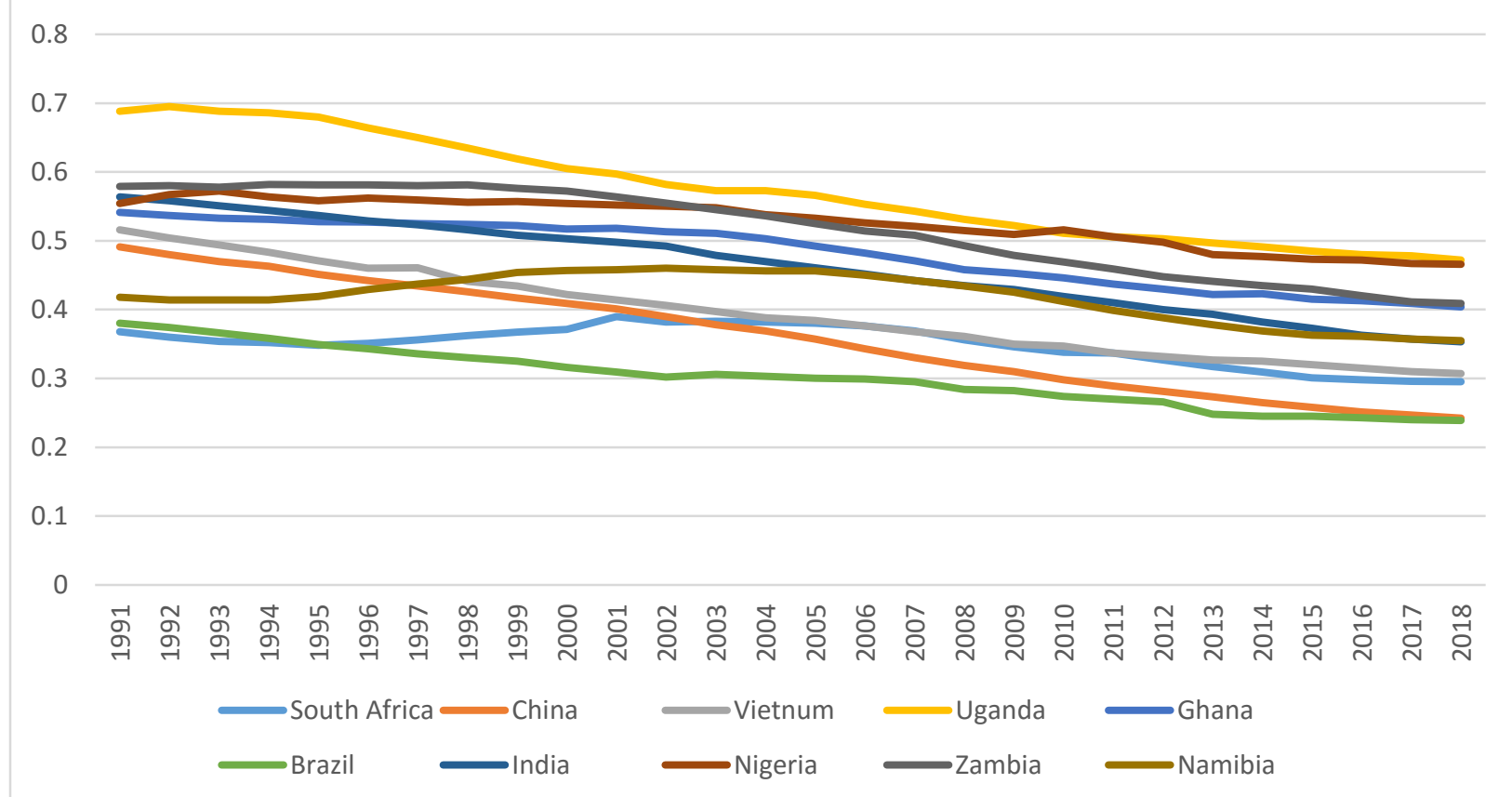

Source: International labour Organisation ILOSTATS

However, when the sample time average rate of poverty change is calculated for period 1991 to 2018. The time average rate of poverty is mathematical represented in Equation (1).

$$
T A P=\frac{\sum\left(p_{i t}-p_{i t-1}\right)}{n-1}, i=1,2, \ldots, n \text { and } t=1,2, \ldots, T \text {. }
$$

Where

$T A P=$ the time average poverty rate change of country $i$ in the period year $t$.

$p_{i t}=$ the poverty rate of country $i$ in year $t$.

$p_{i t-1}=$ the poverty rate of country $i$ in for the previous period year $t$.

$n=$ is the total number of periods in years for each panel country $i$ for which the data relates to.

Based on Equation (1) computations, countries can be logically classified into either positive poverty reduction or negative poverty reduction countries. Positive poverty reduction economies 


\section{SOCIAL SCIENCES IN THE 21ST CENTURY}

have poverty levels decreasing at an increasing rate with a resultant negative time average poverty rate change whereas negative poverty reduction economies have poverty rate also reducing but at a decreasing rate resulting in a positive time average poverty rate change during the study period. Based on this comparison, six countries fall into positive poverty reduction economies while four are in the negative poverty reduction category (See Table 1).

As a result, Brazil, China, India, Namibia, South Africa and Vietnam are positive poverty reduction economies while Ghana, Nigeria, Uganda and Zambia are negative poverty reduction economies based on the sample time average rate of poverty change from 1991 to 2018. The rest of the variables used in the paper are defined hereunder.

TABLE 1: POSITIVE AND NEGATIVE POVERTY REDUCTION ECONOMIES

\begin{tabular}{|l|c|c|l|}
\hline Country & $\begin{array}{c}\text { Time average rate of poverty } \\
\text { reduction change }\end{array}$ & Ranking & Economic classification \\
\hline Vietnam & -0.000333333 & 1 & Positive poverty reduction \\
\hline South Africa & -0.000259259 & 2 & Positive poverty reduction \\
\hline China & -0.000222222 & 3 & Positive poverty reduction \\
\hline Brazil & -0.000185185 & 4 & Positive poverty reduction \\
\hline India & -0.000007407 & 5 & Positive poverty reduction \\
\hline Namibia & -0.000007408 & 6 & Positive poverty reduction \\
\hline Ghana & 0.000003704 & 7 & Negative poverty reduction \\
\hline Zambia & 0.000111111 & 8 & Negative poverty reduction \\
\hline Uganda & 0.000481481 & 9 & Negative poverty reduction \\
\hline Nieria & 0.000518519 & 10 & Negative poverty reduction \\
\hline
\end{tabular}


Poverty rate is derived from the human development index (HDI) which is a standard measure of the quality of life (World Bank, 2018b). The higher the HDI of a country the lover the poverty level and vice-versa. The poverty rate is therefore measured as the rate of deviation of the HDI from a unitary value, that is, one minus the HDI (1-HDI = poverty rate) and is the dependent variable. The head count index is the commonly used measure for poverty (Castleman et al., 2015; Touray, 2016). Countries' data on head count index is however very unbalanced and hence an alternative proxy was used instead. Unemployment rate is the independent variable defined as the total unemployed population as a percentage of the total labour force. Unemployment rate has a significant effect on increasing the poverty as the increase of unemployment rate intensified poverty (Kashi \& Tash, 2014; Kyzyma, 2018). Therefore the study expects a positive relationship between unemployment rates and poverty levels. Inflation rate is also another independent variable defined as the rise in the aggregate level of prices for goods and services. Depending on the cause of inflation and the structure of the economy, the effect of price increases on poverty can be either negative or positive (Hertel \& Winters, 2006; Ivanic \& Martin, 2008; Ravallion \& Lokshin, 2005; World Bank, 2018a). Therefore the study expects a unidirectional relationship between inflation rates and poverty. Interest rates is the independent variable recorded as the average annual borrowing interest rate charged by banks to the private sector. High interest rates burden borrowers which increases poverty (Ekobena \& Yannick, 2012; Fan \& Chan-kang, 2005). Therefore this study expects a positive relationship between interest rates and poverty. The study used secondary country data compiled from the International Monetary Fund, International Labour Organisation and World Bank from 1991 to 2018.

\subsection{Model estimation}

Given the time series cross sectional country data and the need to understand macroeconomic factors on poverty levels across countries, the study followed a panel data analysis using the fixed effects model. The fixed effects model is adopted ahead of the random effects model in line with the significant the Hausman Test's chi square statistic (Table 3). The fixed effects model mathematical estimation is represented below in Equation (2).

$$
Y_{i t}=\alpha_{i t}+\beta \mathrm{X}_{i t}+\mu_{i t}, i=1,2, n \text { and } t=1,2, T \text {. }
$$

Where

$Y_{i t}=$ the poverty rate of country $i$ in year $t$.

$\alpha_{i}=$ the country-specific intercepts that capture heterogeneities of the respective countries.

$\mathrm{X}_{i t}=$ represents each independent variable i.e. interest rate, inflation rate or unemployment rate for country $i$ at time $t$ affecting poverty outcome.

$\beta=$ is the coefficient for each of the independent variables.

$\mu_{i t}=$ is the error term 


\section{Results}

The summary statistics are presented first (Table 2), followed by the main results (Table 3). The mean and median values for poverty are almost equal indicating a low variance in the data series. However, for unemployment, inflation and interest rates the variance between the mean and median is large suggesting that some countries experienced high levels of change for each of these variables in the series. Outliers in the series are as a results prevalent in some countries. Furthermore, the dependent variable; poverty is normally distributed with a skewness of approximately zero and also mesokurtic with a 2.9 score for distribution of kurtosis. However, all the independent variables are leptokurtic showing signs of peaked curves and long-right tailed distributions indicating that unemployment, inflation and interest rates series contain more data with higher values than the sample mean. Therefore, thus the data has to be transformed by taking a $\log$ of all the data set before using it in the main analysis.

TABLE 2: SUMMARY STATISTICS

\begin{tabular}{lcccc}
\hline & POVERTY & UNEMPLOYMENT & INFLATION & INTEREST \\
\hline Mean & 0.436915 & 9.086911 & 31.29107 & 23.15005 \\
Median & 0.437000 & 4.750000 & 8.150000 & 17.97400 \\
Maximum & 0.695000 & 33.47000 & 2080.000 & 128.8200 \\
Minimum & 0.044200 & 0.920000 & -1.800000 & 4.350000 \\
Std. Dev. & 0.103356 & 8.630303 & 179.6201 & 19.38375 \\
Skewness & -0.075389 & 1.204001 & 10.09448 & 2.499839 \\
Kurtosis & 2.940476 & 3.150854 & 108.3651 & 10.89699 \\
\hline Jarque-Bera & 0.306565 & 67.91432 & 134276.4 & 1019.191 \\
Probability & 0.857888 & 0.000000 & 0.000000 & 0.000000 \\
\hline Sum & 122.3362 & 2544.335 & 8761.500 & 6482.013 \\
Sum Sq. Dev. & 2.980389 & 20780.52 & 9001487. & 104828.6 \\
\hline Observations & 280 & 280 & 280 & 280 \\
\hline
\end{tabular}

Three sets of results are presented (Table 3) for the main results. First the effects of interest, unemployment and inflation rates on poverty are presented for positive poverty reduction economies for individual countries referred to as Model 1, followed by results on negative poverty reduction countries referred to as Model 2 and lastly are results for all the countries combined referred to as Model 3. The results display the coefficient of each independent variable which indicates the effects the variable has on poverty, accompanied by the corresponding standard errors and the significance levels. As alluded above, the fixed effects model is appropriate for this study based on a statistically significant Hausman test and the data also fit the model for normality, heteroskedasticity and multicollinearity (Table 3). 


\begin{tabular}{llll}
\hline Model 1 & Interest rate & Unemployment rate & Inflation rate \\
\hline Brazil & $0.0014 * * *(0.0016)$ & $-0.0049 * * *(0.0021)$ & $-3.7900(8.4701)$ \\
China & $0.01512 *(0.00903)$ & $-0.0680 * * *(0.0161)$ & $-0.0030(0.0026)$ \\
India & $0.0234 * *(0.0024)$ & $0.1037 * * *(0.0301)$ & $0.0023(0.0023)$ \\
Namibia & $0.0031(0.0051)$ & $0.0041(0.0102)$ & $0.0015(0.0060)$ \\
South Africa & $0.00210(0.00199)$ & $0.00474 * *(0.0022)$ & $-0.0006(0.0022)$ \\
Vietnam & $0.0073 * * *(0.0007)$ & $0.0649 * * *(0.0095)$ & $-0.0007 *(0.0003)$ \\
\hline
\end{tabular}

\section{Model 2}

\begin{tabular}{llll}
\hline Ghana & $0.0029 * * *(0.0012)$ & $-0.0062(0.0060)$ & $0.0010(0.0007)$ \\
Nigeria & $0.0041 * * *(0.0013)$ & $-0.0241 * * *(0.0053)$ & $0.0011(0.0067)$ \\
Uganda & $0.0025(0.0045)$ & $0.0518(0.0314)$ & $0.0043 *(0.0022)$ \\
Zambia & $0.0011 * *(0.0005)$ & $0.0012 * * *(0.0026)$ & $-0.0005 *(0.0002)$ \\
\hline
\end{tabular}

Model 3

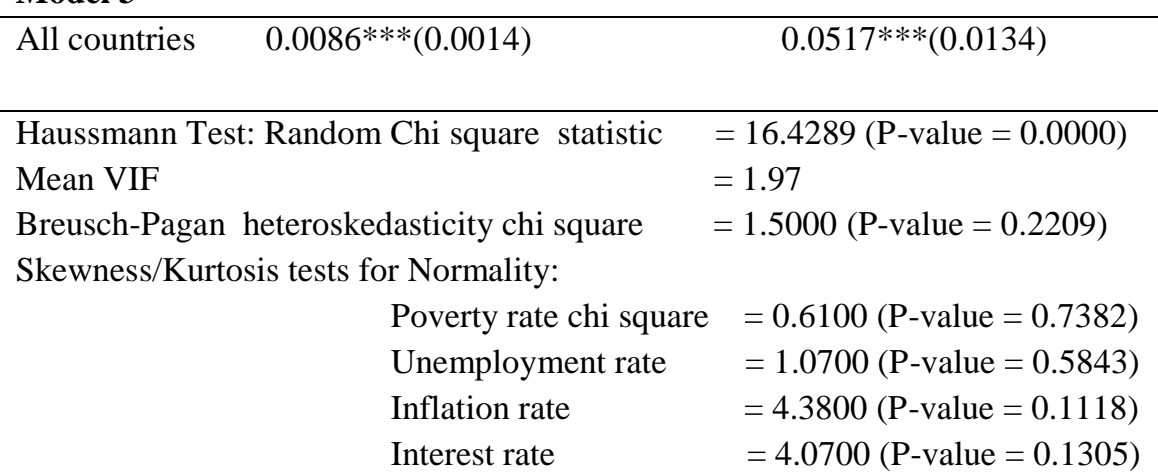

Standard Errors in parenthesis; $(*),[* *],\{* * *\}=(10 \%),[5 \%],\{1 \%\}$

\section{Discussion of Results}

The results of the fixed effects model lead to the following findings. Inflation rate has both positive and negative effects on poverty in both positive and negative poverty reduction economies, although this is only significant for developing countries, namely Uganda, Vietnam and Zambia. This results are consistent with evidence from other previous studies (Dulani et al., 2013; Hertel \& Winters, 2006; Ivanic \& Martin, 2008; Ravallion \& Lokshin, 2005) which state that the direction of the effects of inflation on poverty depend on the structure of the economy and its response to inflation therefore may vary (O’Shea, Yablonski, Murthy, \& Davis, 2012). For Uganda, the relationship is positive, signifying a developing country characterised mainly by low and middle income populations. In such a case, the middle income population is the most affected by inflation whose investment savings are eroded by inflation and are easily downgraded to the poverty group thus increasing poverty levels. In contrast, for Zambia and Vietnam the relationship 
is negative resembling economies with high income distribution inequalities, currently with Ginicoefficients of 0.74 (IGC, 2017) and 0.4 (World Bank, 2019) respectively. In this case, the very rich population holding most of the savings in the economy are unlikely to downgrade to the poverty group as their huge assets are less sensitive to inflation loses than that of the low and middle income groups and thus poverty negligibly respond to inflation rate pressure. The level of income inequality matters in determining the effects of inflation in an economy (Anwar et al., 2018). There is therefore a need to promote economic policies that aim at reducing economic exclusion through reducing income distribution inequality so that efforts to reducing poverty via inflation control targeted interventions lead to positive poverty reduction.

Unemployment rate and poverty rate relationship for both the positive and negative poverty reduction countries is both positive and negative and also significant except for Ghana, Uganda and Namibia. However, from theory the relationship should be positive (Fan \& Chan-kang, 2005; Keynes, 1936) meaning Brazil, China and Nigeria with negative relationships must be accounted for by unique national characteristics. This results are consistent with evidence from other studies that the relationship can be positive (Budiantara et al., 2011; Nwagwu, 2014) due to low personal capacity development and low employment absorption capacity of the population but can also be negative (Agenor, 2016; Christiansen, Chuhan-Pole, \& Sanoh, 2013) due to extensive subsidies to the poor or high taxes on the employed workforce to fund subsidies. Undoubtedly, India, Uganda, Vietnam and Zambia with significant positive unemployment and poverty rate relationship signify low personal capacity development and low employment absorption capacity levels (Keynes, 1936; Lawrance, 1991; Townsend, 1979). While South Africa may not be heavily affected as other countries, low tax rates in the economy channeled towards pro-poor subsidies trades-off the benefits of high personal development and absorption capacity of the economy (Dulani et al., 2013; Weiping, 2018). Meanwhile, China, Brazil and Nigeria with negative relationship between unemployment and poverty rates signify the presence of high subsides but the associated high taxes reduces the purchasing power of the working population (Collins \& Wanjau, 2011). Thus, while unemployment is reducing for these economies poverty continue to rise in these economies.

Interest rate and poverty rate are positively related and significant for both positive and negative poverty reduction economies. Again this is in line with theory (Keynes, 1936; Lawrance, 1991) and evidence from other studies (Collins \& Wanjau, 2011; Ekobena \& Yannick, 2012; A. Khan, 2007). However, for Uganda, Namibia and South Africa even if the relationship is positive it was insignificant. Supporting the view that some of these economies have very good starting conditions (Christiansen et al., 2013; Weiping, 2018). For example, South Africa and Namibia have very good pro-poor social support grant systems (Dulani et al., 2013) targeted to funding both education and household needs which then reduces the need for a high dependence on loans as a source of income for the low and middle income classes. Therefore, the presence of a sustainably funded and properly managed pro-poor grant system may reduce the dependence of households from private credit markets for finance thereby negating the trade-off effects of interest rate costs on poverty. 


\section{Conclusion}

When all the ten countries are included, only interest rate and unemployment rate has an effect on poverty reduction while inflation does not have an effect. When countries are grouped into positive and negative poverty reduction economies the effects of interest rate and unemployment rate are the same but with varying country individualistic characteristics. The results show that poverty rate is more rooted on the ability of the population to access funds from either employment income or access to financial markets than on prices of goods and services. This also implies while countries are generally affected by interest rates and unemployment rates however different policies need to be implemented to reduce poverty based on unique characteristics of the country rooted the level of income distribution in the economy and structure of the economy in terms of income classification status as low, middle or high income level. The intervening policies implemented based on the above features will yield the same results whether a country is a positive or negative poverty reduction economy, meaning this classification does not matter for the purposes of policy targeting. Rather emphasis must be placed on the determining factors taking into account individualistic country characteristics and not necessarily the classification.

\section{Acknowledgement}

This paper is an output of a Master of Science in Finance and Investment dissertation submitted by the first author and supervised by the second author at the National University of Science and Technology.

\section{References}

Agenor, P. (2016). Caught in the middle? The economics of middle-incomes traps. Journal of Economic Surveys, 00(00), 1-21.

Anwar, A., Zaman, Q. U., Amir, M., \& Amin, W. (2018). The Relationship between Poverty , Income Inequality and Unemployment : Evidence from ARDL and Bound Testing Approach. Journal of Natural and Social Sciences, 7(1), 42-53.

Banerjee, A., Galiani, S., Levinsohn, J., McLaren, Z., \& Woolard, I. (2008). Why has unemployment risen in the New South Africa ? Economics of Transition, 16(4), 715-740.

Bourguignon, F. (2004). The Poverty-Growth-Inequality Triangle. Washington DC.

Budiantara, I. N., Diana, R., \& Darmesto, S. (2011). Relationship Pattern of Poverty and Unemployement in Indonesia. International Journal of Basic and Applied Sciences, 11(6), 119-127.

Castleman, T., Foster, J., \& Smith, S. C. (2015). Person Equivalent Headcount Measures of Poverty. George Washington.

Christiansen, L., Chuhan-Pole, P., \& Sanoh, A. (2013). Africa's growth, poverty and inequality nexus- Fostering shared properisty, (July), 1-35.

Collins, N. J., \& Wanjau, K. (2011). The effects of interest rate spread on the level of nonperforming assets : A case of commercial banks in Kenya. International Journal of Business and Public Management, 1(April), 58-65.

Datt, G., \& Ravallion, M. (2002). Is India 's Economic Growth Leaving the Poor Behind? Dehli. 
Davis, P., \& Sanchez-martinez, M. (2014). A review of the economic theories of poverty. London.

Davis, P., \& Sanchez-martinez, M. (2015). Economic theories of poverty. London.

Dulani, B., Mattes, R., \& Logan, C. (2013). After a Decade of Growth in Africa, Little Change in Poverty at the Grassroots (Vol. 18). Lilongwe.

Easterly, W., \& Fischer, S. (2001). Inflation and the Poor. Journal of Money, Credit and Banking, 33(2), 2001.

Ekobena, F., \& Yannick, S. (2012). Does monetary policy really affect poverty?

Epstein, G., Heintz, J., Ndikumana, L., \& Chang, G. (2010). Gerald Epstein, James Heintz, Léonce Ndikumana, and Grace Chang (No. 58). Geneva.

Fan, S., \& Chan-kang, C. (2005). Road Development, Economic Growth, and Poverty Reduction in China.

Handley, G., Higgins, K., Bird, K., \& Cammack, D. (2009). Poverty and poverty reduction in subSaharan Africa: An overview of the issues (No. 299). London. Retrieved from ODI Working papers Online ISSN 17592917

Hertel, T. W., \& Winters, A. L. (2006). Poverty and the WTO. Geneva.

IGC. (2017). Growth and income inequality in Zambia. Cape Town.

Ioris, A. A. R. (2016). The paradox of poverty in rich ecosystems: Impovershment and development of the Amazon of Brazil and Bolivia. Royal Goegraphical Society with the Insitute of British Geograph, 10(111), 1-13.

Ivanic, M., \& Martin, W. (2008). Implications of higher global food prices for poverty in lowincome. Agricultural Economics, 39(4), 405-416.

Kashi, F. K., \& Tash, M. N. S. (2014). Effects of macroeconomic variables on poverty in Iran ( Application of bootstrap technique ). Theoretical and Applied Economics, XXI(5), 85-96.

Keynes, J. M. (1936). The General Theory of Employment, Interest, and Money. (K. College, Ed.) (1st ed.). Zurich: Inetrnational Relations and Security Network.

Khan, A. (2007). Growth, employment and poverty: An analysis of the vital nexus based on some recent UNDP and ILO / SIDA studies. Economic and Social Affairs, 1(49), 1-45.

Khan, B. U. I., Langoo, A. A., Olanrewaju, F. F., Baba, A. M., \& Assad, S. (2017). A Compendious Study of Online Payment Systems: Past Developments, Present Impact, and Future Considerations. International Journal of Advanced Computer Science and Applications, 8(5), 256-271.

Krantz, L. (2001). The Sustainable Livelihood Approach to Poverty Reduction.

Kyzyma, I. (2018). How Poor Are the Poor? Looking Beyond the Binary Measure of Income Poverty. Luxemberg.

Lawrance, E. C. (1991). Poverty and the Rate of Time Preference : Evidence from Panel Data. Journal of Political Economy, 99(1), 54-77.

Loayza, N. V, \& Raddatz, C. (2010). The composition of growth matters for poverty alleviation. Journal of Development Economics, 93(1), 137-151.

Nwagwu, E. J. (2014). Unemployment and poverty in Nigeria: A link to national insecurity. Global Journal of Politics and Law Research, 2(1), 19-35.

O'Shea, S., Yablonski, J., Murthy, S., \& Davis, K. (2012). Equity highlights in this issue. Washington DC. 
Ravallion, M. (2010). A Comparative Perspective on Poverty Reduction in Brazil, China , and India. The World Bank Research Observer, 26(1), 71-104.

Ravallion, M. (2012). Poverty Lines Across the World. Washington DC.

Ravallion, M., \& Lokshin, M. (2005). Who Cares about Relative Deprivation? (No. WPS3782). Washington DC.

Romer, C. D., \& Romer, D. H. (1998). Monetary policy and the well-being of the poor (NBER No. 6793). Cambridge.

Sabir, H. M., \& Tahir, S. H. (2012). The impact of different macroeconomic variables on poverty in Pakistan. Interdisciplinary Journal of Contemporary Research in Business, 3(10), 788799.

Sembene, D. (2015). Poverty, Growth and Inequality in Sub-Sahara Africa: Did the Walk match the Talk under PRSP Approach? (No. WP/15/122). Washington DC.

Siyan, P., Adegoriola, A., \& Adolphus, J. A. (2017). Unemployment and inflation: Implication on poverty level in Nigeria. MPRA.

Touray, M. (2016). Definitions and measures of poverty. Development Initiatives. Nairobi.

Townsend, P. (1979). Poverty in the United Kingdom A Survey of Household Resources and Standards of Living (1st ed.). Middlesex, England: Penguin Books Ltd.

UNECA. (2016). Nigeria country profile 2016. Addis Ababa.

Weiping, T. (2018). China's Approach to Reduce Poverty: Taking Targeted Measures to Lift People out of Poverty. Addis Ababa.

World Bank. (2018a). Overcoming poverty and inequality in South Africa: An assessment of drivers, constraints and Opportunities. Washington DC.

World Bank. (2018b). Poverty and shared prosperity. Washington DC.

World Bank. (2019). Vietnam Gini Coefficient World bank Estimates. Washington DC. 